DOI 10.14746/ssp.2019.1.4

\author{
Rafał CZaChor
}

Uczelnia Jana Wyżykowskiego

ORCID: 0000-0002-5929-9719

\title{
Ustrój samorządu lokalnego w Republice Mołdawii. Ewolucja i stan obecny
}

\begin{abstract}
Streszczenie: Mołdawia jest państwem, które z jednej strony podejmuje wysiłki zmierzające ku demokratyzacji i europeizacji jej systemu politycznego i prawnego, z drugiej - działania te są chaotyczne, brak im konsekwencji i są uwarunkowane bieżącą sytuacją polityczną. Jednym z obszarów podlegających takim politycznym przesileniom jest samorząd terytorialny. Cele artykułu są dwojakie: po pierwsze, periodyzacja i charakterystyka kolejnych etapów kształtowania się modelu samorządu lokalnego w Mołdawii, po drugie - charakterystyka aktualnie obowiązujących rozwiązań i wskazanie podstawowych problemów istotnie wpływających na jego funkcjonowanie.
\end{abstract}

Słowa kluczowe: samorząd lokalny, demokratyzacja, decentralizacja władzy publicznej, Mołdawia

\section{Wstęp}

D epublika Mołdawii jest jednym z przykładów niezakończonej deLmokratyzacji postradzieckiej, gdzie procesy demokratycznej transformacji okresowo hamowane są nawrotami zjawisk o zgoła przeciwnym charakterze. Skutecznym paradygmatem opisu przemian w Mołdawii może być podejście neopatrymonialne, w którym zwraca się uwagę, że funkcjonowanie instytucji publicznych pozostaje funkcją interesów głównych grup interesu, klanów i koterii dokonujących procederu ,zawłaszczania państwa" (state capture). Zjawiska te bardzo wyraźne są w mołdawskim samorządzie lokalnym, którego ustrój ewoluuje wraz ze zmieniającymi się interesami elit władzy (Czachor, 2015). Celem poniższego artykułu jest omówienie procesu kształtowania się współczesnego (po uzyskaniu niepodległości w 1991 roku) modelu samorządu lokalnego w Mołdawii, wskazanie problemów w jego funkcjonowaniu oraz kierunków ewentualnych reform. Zagadnienie to wydaje się szczególnie 
aktualne w związku z postępującym zbliżeniem Mołdawii z Unią Europejską, m.in. wskutek podpisania umowy stowarzyszeniowej. Efektywny samorząd lokalny jest jednym z podstawowych elementów nowoczesnego państwa demokratycznego. Jego petryfikacja w przypadku Mołdawii prawdopodobnie potrwa długo, lecz jest nieodzownym elementem europeizacji. Innym istotnym czynnikiem rzutującym na charakter i zakres reform samorządowych jest utrzymywanie się nierozwiązanego od początku lat 90. konfliktu z pozbawionym powszechnego uznania parapaństwem - Naddniestrzem oraz funkcjonowanie w składzie Mołdawii autonomicznej Gagauzji.

\section{Periodyzacja ewolucji samorządu lokalnego}

Proces kształtowania się samorządu lokalnego w Mołdawii - wciąż jeszcze niezakończony - można scharakteryzować jako cyklicznie zmieniające się trendy: ku decentralizacji i wzmocnieniu samorządu oraz przeciwstawny - ku centralizacji i ograniczeniu samorządności lokalnej.

Etap pierwszy obejmuje lata 1991-1997. Był to czas stanowienia nowoczesnej mołdawskiej państwowości, przyjmowania podstawowych aktów prawnych oraz działań zbrojnych mających na celu pokonanie separatyzmu naddniestrzańskiego i gagauskiego. W tym czasie została przyjęta m.in.:

- konstytucja Mołdawii uchwalona przez parlament 29.07.1994 r. (Konstytucja, 2014);

- ustawa z dn. 7.12.1994 r. o podziale administracyjno-terytorialnym kraju (Lege nr 306-XIII);

- ustawa z dn. 23.12.1994 r. o szczególnym statusie prawnym Gagauzji (Lege nr 344-XIII);

- ustawa z dn. 19.04.1995 r. o mieście stołecznym Kiszyniowie (Lege nr 431-XIII).

Ustawa zasadnicza Republiki Mołdawii stanowi, iż jest ona państwem unitarnym - ,jednolitym i niepodzielnym” (art. 1). Kwestii samorządu lokalnego poświęcone są artykuły 110-112. Konstytucja głosi, że ,administracja publiczna $\mathrm{w}$ jednostkach administracyjno-terytorialnych jest tworzona zgodnie z zasadą autonomii lokalnej, decentralizacji usług publicznych, wybieralności organów lokalnej administracji publicznej i konsultacji z obywatelami w sprawach lokalnych o doniosłym znaczeniu" (art. 109). 
Po uzyskaniu niepodległości w Mołdawii utrzymano istniejący w czasach radzieckich dwustopniowy podział administracyjny. Szczebel podstawowy stanowiły gminy miejskie (commune) i wiejskie (sate), szczebel drugi - rejony (raion) i miasta znaczenia republikańskiego (municipium, miasto na prawach rejonu). Liczba gmin przekraczała 960, podczas gdy rejonów - 40, a miast znaczenia republikańskiego było 10 (w tym na terenie separatystycznego Naddniestrza). Każda wieś stanowiła odrębną jednostkę administracyjną. Ze względu na niewielki obszar państwa, nie wprowadzono tu trzeciego szczebla - obwodowego, funkcjonującego m.in. na Ukrainie czy Białorusi. Kwestię podziału administracyjno-terytorialnego uregulowano konstytucyjnie, gwarantując autonomię Gagauzji jako ,autonomicznej jednostki terytorialnej o szczególnym statusie będącej formą samostanowienia Gagauzów" (art. 111 Konstytucji). W obawie przed dalszym rozwojem separatyzmu gagauskiego została też przyjęta wspomniana ustawa regulująca status polityczno-prawny Gagauzji. Jednostka ta posiada własny organ prawodawczy - Zgromadzenie Ludowe oraz monokratyczną egzekutywę w osobie baszkana. Jemu też podlegają wszystkie lokalne organy władzy publicznej. Przyjęcie tej ustawy postrzegane jest jako akt kończący, trwający od czasów pierestrojki, konflikt pomiędzy rządem Mołdawii a gagauskim ruchem separatystycznym (Макухин, 2017, s. 131).

Ustawa z dn. 7.12.1994 r. o podziale administracyjno-terytorialnym kraju, obowiązująca od 1997 roku, zmieniła podział administracyjno-terytorialny państwa. Zlikwidowano miasta znaczenia republikańskiego: $4 \mathrm{z}$ nich przekształcono w rejony, a więc de facto ich sytuacja nie uległa zmianie, pozostałe - zostały włączone do okalających je rejonów. Potwierdzono wówczas też autonomię gagauską, która nominalnie składała się z 3 rejonów i dokonano częściowej konsolidacji gmin.

Etap drugi trwał w latach 1997-2001. Jego główną cechą charakterystyczną była modernizacja i decentralizacja władzy publicznej. Punktem przełomowym było ratyfikowanie w 1997 roku przez władze Mołdawii bez zastrzeżeń Europejskiej Karty Samorządu Lokalnego. Następnie dokonano szeregu zmian w ustroju samorządu terytorialnego, przyjmując m.in.:

- ustawę z dn. 12.11.1998 r. o podziale administracyjno-terytorialnym kraju (Lege nr 191-XIV);

- ustawę z dn. 6.11.1998 r. o lokalnej administracji publicznej (Lege nr 186-XIV).

Celem reformy administracyjno-terytorialnej była konsolidacja jednostek pierwszego i drugiego szczebla i zwiększenie ich efektywności. 
Na szczeblu pierwszym zniesiono część gmin, tak że ich liczba oscylowała wokół 900 . Na szczeblu drugim rejony zastąpiono 9 powiatami (judeţ, włączając Naddniestrze). Dawne miasta na prawach rejonów ( $m u$ nicipium) zostały siedzibami nowych powiatów, co oznaczało podniesienie ich znaczenia. W randze równej powiatowi funkcjonowały jednostki, których status regulowało odrębne ustawodawstwo: stołeczny Kiszyniów, autonomiczna Gagauzja, możliwość taką nadano jednostkom położonym na lewym brzegu Dniestru (Naddniestrze).

Ustawa z dn. 6.11.1998 r. o lokalnej administracji publicznej wprowadziła instytucję prefekta - istniejącą w przeszłości, gdy Besarabia wchodziła w skład Rumunii w latach 1918-1940. W każdej jednostce administracyjno-terytorialnej drugiego stopnia, jednostkach autonomicznych oraz mieście stołecznym Kiszyniowie funkcjonował powoływany przez rząd i będący jego terenowym reprezentantem prefekt. Podlegały mu terenowe delegatury administracji centralnej, był organem nadzoru nad działalnością samorządu lokalnego. Nadzór nie oznaczał jakkolwiek hierarchicznej podległości organów samorządowych prefektowi. Upoważniony był on do wydawania zarządzeń. Na wniosek prefekta rząd powoływał jego jednego lub dwóch zastępców (subprefektów), którzy wraz $\mathrm{z}$ innymi urzędnikami tworzyli organ administracji - prefekturę.

Reforma była krytykowana przez ówczesną opozycję - partie lewicowe, zwłaszcza komunistów - jako „bezrefleksyjne kopiowanie rozwiązań obowiązujących w Rumunii” (Макухин, 2017, s. 133). Trudno dokonać oceny tej reformy, bowiem okres obowiązywania nowych rozwiązań był zbyt krótki. Reforma naruszyła trwający od czasów radzieckich układ lokalnych nieformalnych powiązań i zależności, toteż była krytykowana przez środowiska, które na niej najbardziej straciły. Samą ideę decentralizacji lokalnej władzy publicznej w Mołdawii, równoważoną wprowadzeniem instytucji prefekta, należy ocenić za słuszną i odpowiadającą potrzebom państwa.

Trzeci etap reform obejmował lata 2001-2005. Był to czas odwrotu od wcześniejszych koncepcji, narastania tendencji centralizacyjnych. Ich przyczyną było przejęcie władzy przez Komunistyczną Partię Mołdawii, która jednoznacznie krytykowała reformę wprowadzaną w poprzednich latach. Zmian recentralizacyjnych dokonano w rzeczonym okresie w drodze przyjęcia:

- ustawy z dn. 27.12.2001 r. o podziale administracyjno-terytorialnym kraju, znoszącej powiaty i przywracającej rejony (Lege nr 764-XV);

- ustawy z dn. 18.03.2003 r. o lokalnej administracji publicznej (Lege nr 123-XV); 
- ustawy z dn. 16.10.2003 r. o finansach $i$ własności jednostek administracyjno-terytorialnych (Lege $\mathrm{nr}$ 397-XV).

Istotnym wydarzeniem tego okresu była nowelizacja ustawy określającej podział administracyjno-terytorialny Mołdawii. Reorganizacja objęła drugi szczebel administracji. Zlikwidowano powiaty, które zostały zastąpione większą liczbą rejonów. W praktyce było to przywrócenie podziału będącego dziedzictwem epoki radzieckiej i obowiązującego do 1998 roku. Rządząca Komunistyczna Partia Mołdawii twierdziła, że podział na powiaty nie sprawdził się, władze powiatowe są zbyt oddalone od ludności i mniej efektywne niż w poprzednim modelu. $\mathrm{Z}$ tego powodu odtworzono strukturę rejonów - powstało ich 32, zaś liczba gmin wynosiła 898 . W praktyce przywrócenie dawnych rozwiązań służyło politycznym celom i odbudowie klientelistycznych relacji pomiędzy centrum a peryferiami, znanych jeszcze z okresu radzieckiego.

Forsowane przez posiadającą większość mandatów w parlamencie Komunistyczną Partię Mołdawii zmiany były sprzeczne z normami konstytucyjnymi, co znalazło potwierdzenie w orzecznictwie Sądu Konstytucyjnego. Za takie uznano m.in. wprowadzenie pośredniego wyboru burmistrzów przez lokalne ciała uchwałodawcze oraz możliwość ich odwołania przez odpowiednią radę jednostki drugiego szczebla.

Kryzys konstytucyjny doprowadził do przyjęcia nowej ustawy o lokalnej administracji publicznej z dn. 18.03.2003 r. Oprócz określonych zmian wynikających z zastąpienia powiatów rejonami, zlikwidowano instytucję prefekta.

Czwarty, współczesny etap rozwoju mołdawskiego samorządu lokalnego, rozpoczął się w roku 2005. Związany jest on z postępem we współpracy Mołdawii z Unią Europejską i przyjęciem Planu Działania (Action Plan). Przyjęta w tym okresie została m.in.:

- ustawa z 22.07.2005 r. o szczególnym statusie prawnym Naddniestrza (Lege nr 173-XVI);

- ustawa z 28.12.2006 r. o decentralizacji administracji (Lege $\mathrm{nr}$ 435-XVI);

- ustawa z 28.12.2006 r. o lokalnej administracji publicznej (Lege nr 436-XVI).

Ustawa o decentralizacji administracji przyniosła prawne potwierdzenie osobowości prawnej i autonomii jednostek samorządu lokalnego, które odtąd działają „w interesie społeczności lokalnej i na własną odpowiedzialność". Samorząd lokalny funkcjonuje, zgodnie z ustawą, w oparciu o zasady subsydiarności, równości, integralności, odpowiedniości zasobów i zadań, solidarności finansowej, dialogu instytucjonalne- 
go, partnerstwa publiczno-prywatnego i rozliczalności. Ustawa określiła 3 kategorie kompetencji jednostek samorządu lokalnego: własne, delegowane i współdzielone. Zadania delegowane są zadaniami władz centralnych przekazanych do wykonania jednostkom samorządowym i muszą być finansowane z budżetu państwa.

Likwidacja instytucji prefekta spowodowała przekazanie jego kompetencji Ministerstwu Lokalnej Administracji Publicznej, które istniało do 2009 roku. Po jego likwidacji poszczególne zadania, ze względu na właściwość, przekazano innym resortom. Spowodowało to szereg trudności i konieczność koordynowania działań przez samorządy z różnymi ministerstwami.

\section{Współczesny ustrój samorządu lokalnego}

Obecnie w Mołdawii istnieje 898 jednostek pierwszego szczebla (gmin miejskich i wiejskich) oraz 32 jednostki drugiego szczebla (rejony), ponadto statusem jednostki drugiego szczebla dysponują dwa największe miasta - stołeczny Kiszyniów i Bielce. Status terytorium autonomicznego posiada Gagauzja, zaś autonomię przewiduje się również dla Naddniestrza.

Organy gminy. Organem prawodawczym na szczeblu gminy są rady. Liczba członków rady zależy od liczby ludności gminy. Status prawny radnych samorządowych reguluje ustawa z dn. 2.02.2000 roku (Lege nr 768-XIV), zaś tryb wyboru - ustawa (kodeks wyborczy) z dn. 21.11.1997 roku (Lege nr 1381-XIII). Kadencja trwa 4 lata, zaś dla ważności wyborów niezbędne jest przekroczenie poziomu 25\% frekwencji. Kandydatów na radnych zgłaszać mogą partie polityczne, organizacje społeczne oraz komitety wyborcze. Obowiązuje zasada incompatibilitas w wariancie zbliżonym do polskiego: osoby pełniące funkcje samorządowe nie mogą być deputowanymi parlamentu bądź członkami rządu. Burmistrzowie nie mogą zajmować się żadną działalnością zarobkową, oprócz naukowej i artystycznej.

Organem wykonawczym na szczeblu gminy jest burmistrz (primar). Ustawa z 28.12.2006 r. o lokalnej administracji publicznej definiuje go jako „organ władzy przedstawicielskiej danej jednostki administracyjnoterytorialnej i organ wykonawczy lokalnej rady wybierany w wyborach powszechnych, równych, tajnych i bezpośrednich". Kadencja wynosi 4 lata. Burmistrz nie ponosi odpowiedzialności przed radą, nie może 
być przez nią pozbawiony urzędu. Odwołanie go możliwe jest wyłącznie w drodze referendum lokalnego. Wiceburmistrzowie są powoływani przez radę na wniosek burmistrza i rada dysponuje prawem ich odwołania (wymagana zgoda $2 / 3$ radnych). Ogółem sprawia to, że organy funkcjonują w dużym stopniu niezależnie od siebie. Pracownicy aparatu samorządowego są członkami służby cywilnej, co oznacza, że ich zatrudnienie możliwe jest przy spełnieniu określonych kryteriów formalnych (w tym znajomość języka urzędowego, zaliczenie egzaminu kompetencyjnego).

Zakres kompetencji gminy. Ustawą o decentralizacji administracji z 28.12.2006 r. określono kompetencje jednostek samorządu lokalnego. Do zadań własnych gmin należy:

a) prowadzenie polityki rozwoju społeczno-ekonomicznego;

b) planowanie zagospodarowania przestrzennego;

c) budowa i utrzymanie gminnej infrastruktury drogowej, wodno-kanalizacyjnej;

d) prowadzenie polityki społecznej;

e) organizacja transportu publicznego;

f) prowadzenie przedszkoli, szkół podstawowych i średnich;

g) prowadzenie instytucji kultury, bibliotek, muzeów, obiektów kultury fizycznej, parków;

h) organizacja handlu na targowiskach, ochrona konsumentów;

i) prowadzenie rejestru aktów stanu cywilnego i nieruchomości (katastru);

j) ochrona przeciwpożarowa;

k) prowadzenie cmentarzy.

Do najczęściej delegowanych zadań, które realizują gminy należy: prowadzenie działań na rzecz aktywizacji bezrobotnych, utrzymanie porządku publicznego, prowadzenie poboru do wojska.

Organy rejonu. Organem uchwałodawczym na szczeblu rejonu jest rada rejonowa. Liczba radnych zależy od liczby mieszkańców danej jednostki. Zasady wyboru radnych rejonowych są analogiczne do zasad obowiązujących w wyborach radnych gminnych.

Organem wykonawczym na szczeblu rejonu jest wybierany przez radę rejonową przewodniczący rejonu. Ponosi on odpowiedzialność polityczną przed radą rejonu i może być przez nią zdymisjonowany (decyzją $2 / 3$ radnych).

Zakres kompetencji rejonu. Do zadań własnych rejonu należy:

a) prowadzenie polityki rozwoju społeczno-ekonomicznego;

b) planowanie zagospodarowania przestrzennego; 
c) budowa i utrzymanie rejonowej infrastruktury drogowej;

d) budowa i utrzymanie obiektów służby zdrowia;

e) zarządzanie placówkami szkolnictwa wyższego;

f) koordynacja i rozwój polityki młodzieżowej i sportu;

g) organizacja transportu publicznego;

h) ochrona środowiska;

i) organizacja przedsięwzięć kulturalnych.

Do najczęściej delegowanych zadań, które realizują rejony należy: prowadzenie szkolnictwa specjalnego i specjalistycznej ochrony zdrowia, zadania z zakresu obrony cywilnej oraz obrony narodowej.

Źródła finansowania. W świetle ustawy z dn. 16.10.2003 r. o finansach $i$ własności jednostek administracyjno-terytorialnych głównymi źródłami dochodów jednostek samorządu lokalnego są: własne dochody budżetowe, podatki i opłaty lokalne, środki uzyskiwanie z prywatyzacji, transfery z budżetu centralnego oraz środki przekazywane przez grantodawców.

\section{Ustrój samorządu lokalnego a problem separatyzmu naddniestrzańskiego i gagauskiego}

Od czasu pierestrojki Mołdawia zmaga się z separatyzmem naddniestrzańskim i gagauskim. Naddniestrze pozostaje obecnie poza kontrolą władz Mołdawii, tworząc jedno z kilku postradzieckich parapaństw. Gagauzja, po okresie napięć z początku lat 90., pozostaje pod kontrolą rządu Mołdawii. Jej szczególny status prawny jest normą konstytucyjną (art. 110-111). Ustawa zasadnicza nie nadaje Naddniestrzu autonomii, aczkolwiek przewiduje taką możliwość (bez sprecyzowania warunków i bez użycia explicite pojęcia Naddniestrze - mowa jest o „miejscowościach leżących na lewym brzegu Dniestru" art. 110, ust. 2). Szczegółowe regulacje normatywne zawiera ustawa z dn. 22.07.2005 r. (Lege nr 173-XVI).

Status prawny Autonomicznej Jednostki Terytorialnej Gagauzja (Kosienkowski, 2007, s. 205-217) określa ustawa zasadnicza Mołdawii, ustawa z dn. 23.12.1994 r. o szczególnym statusie prawnym Gagauzji oraz przyjęty przez parlament statut Gagauzji (Regulamentul Găgăuziei - Gagauz Yeri), regulujący wszystkie kluczowe kwestie ustrojowe.

Organem prawodawczym Gagauzji jest Zgromadzenie Ludowe ( $A d u$ narea Populară a Găgăuziei). Liczy ono 35 deputowanych wybranych w wyborach bezpośrednich w okręgach jednomandatowych. Obowiązuje zasada, by każda miejscowość miała co najmniej jednego przedstawi- 
ciela w Zgromadzeniu i by jeden deputowany przypadał na co najwyżej 5000 mieszkańców. Na czele Zgromadzenia Ludowego stoi jego przewodniczący, jednocześnie kierujący jego prezydium. W zakresie kompetencji lokalnego parlamentu Gagauzji, zgodnie z jej statutem, znajduje się m.in.:

a) przyjmowanie i zmienianie statutu Gagauzji;

b) przyjmowanie uchwał w zakresie: gospodarki komunalnej, ochrony zdrowia, nauki, edukacji i kultury;

c) wprowadzanie podatków lokalnych;

d) zatwierdzanie programów rozwoju społeczno-gospodarczego, prowadzenie polityki społecznej, regulowanie polityki rynku pracy;

e) polityka ochrony środowiska;

f) określanie podziału administracyjno-terytorialnego;

g) wyznaczanie i organizacja referendów lokalnych;

h) współuczestnictwo w formułowaniu i realizacji polityki wewnętrznej i zagranicznej Mołdawii;

i) zatwierdzanie na wniosek głowy Gagauzji składu Komitetu Wykonawczego Gagauzji, kierowników lokalnych administracji;

j) przedstawianie Prokuratorowi Generalnemu Republiki Mołdawii kandydata na Prokuratora Generalnego Gagauzji.

Organem wykonawczym Gagauzji jest jej głowa (baszkan). Jego pozycja ustrojowa uregulowana jest mołdawską ustawą z dn. 23.12.1994 r. o szczególnym statusie prawnym Gagauzji oraz statutem Gagauzji. Wybierany jest w wyborach powszechnych na 4-letnią kadencję. Kandydat na głowę Gagauzji musi spełnić cenzus wieku (ukończone 35 lat), posiadać obywatelstwo mołdawskie oraz znać język gagauski. Możliwość pełnienia urzędu jest ograniczona do dwóch kadencji z rzędu. Na mocy dekretu prezydenta Mołdawii głowa Gagauzji powoływana jest do składu rządu Mołdawii. Baszkanowi podlegają wszystkie organy władzy państwowej w Gagauzji.

\section{Główne problemy funkcjonowania samorządu lokalnego}

Rozdrobnienie gmin i rejonów. Na efektywność samorządu lokalnego w Mołdawii istotny wpływ posiada zbyt duża liczba jednostek administracyjno-terytorialnych. Jest ich bez wątpienia zbyt dużo, szczególnie zważywszy na ich małą liczbę mieszkańców. Około 93\% gmin wiejskich liczy mniej niż 5000 mieszkańców, zaś 50\% gmin - nawet 
mniej niż 2000 mieszkańców. Jest to sprzeczne z normą wspomnianej ustawy z dn. 27.12.2001 r. o podziale administracyjno-terytorialnym kraju, która stanowi, że gminę musi zamieszkiwać co najmniej 1500 osób. Na 100000 mieszkańców Mołdawii przypada 26,4 gminy, podczas, gdy najwyższy wskaźnik rozdrobnienia w Europie Zachodniej notowany jest w Czechach - 24 gminy i Francji - 21 gmin (Munteanu, Chiriac, Berbeca, Vremis, Znaceni, 2017, s. 10). Przy założeniu, że gmina może efektywnie realizować swoje zadania publiczne przy liczbie mieszkańców wynoszącej ponad 5000, można konstatować, że w Mołdawii tylko niewielka ich część spełnia kryterium ilościowe.

Rozdrobnienie administracji terenowej generuje wyższe koszty funkcjonowania administracji publicznej przy jej niskiej efektywności. Koszty utrzymania aparatu administracyjnego w najmniejszych gminach (do 5000 mieszkańców) kształtują się na poziomie około 800 MDL per capita, zaś w gminach większych - około 200 MDL per capita (Munteanu, Chiriac, Berbeca, Vremis, Znaceni, 2017, s. 15). Oznacza to, że sięgają od $10 \%$ wydatków gmin miejskich oraz do $30 \%$ wydatków gmin wiejskich.

Problemy organizacyjno-finansowe. Niewątpliwym problemem mołdawskiego samorządu, i jednocześnie pilnym zadaniem dla władz, jest zagadnienie właściwego podziału kompetencji pomiędzy gminami a rejonami. Chodzi głównie o określenie na nowo celu istnienia rejonów. W obecnej sytuacji ich głównym celem jest pośredniczenie w dystrybucji środków finansowych przekazywanych przez władze republikańskie gminom (Ionescu, Drezgie, Rusu, 2015, s. 13). Tym samym administracje rejonowe są postrzegane jako element politycznej kontroli nad społecznościami gminnymi i są wykorzystywane np. w obliczu wyborów prezydenckich czy parlamentarnych jako tzw. nieformalny ,zasób administracyjny" (ros. - administratiwnyj riesurs). Kłopoty wynikające z rozdrobnienia jednostek administracyjno-terytorialnych pogłębiają trudności finansowe i kadrowe. W około 85\% gmin aparat urzędniczy liczy do 6 pracowników, zaś w 24\% z nich jest to zespół liczący do 4 osób. Kontrastuje to znacząco z sytuacją w administracjach rejonowych, gdzie średnio urząd taki dysponuje 77 etatami (Ionescu, Drezgie, Rusu, 2015, s. 11, 17).

Średni dochód gminy wynosi około 1000 MDL per capita. Najważniejszą pozycją budżetową jest edukacja, która stanowi około 60\% ogółu wydatków (Munteanu, Chiriac, Berbeca, Vremis, Znaceni, 2017, s. 16). W skrajnych przypadkach wydatki na usługi publiczne nie przekraczają 8\% ogółu wydatków danej gminy, zaś pozostałe to koszty utrzyma- 
nia urzędu (Ionescu, Drezgie, Rusu, 2015, s. 8). Sytuacja taka wciąż ma miejsce, mimo iż ustawa z 28.12.2006 r. o decentralizacji administracji określa, że koszty funkcjonowania lokalnych administracji nie mogą przekraczać 30\% dochodów własnych. O słabości finansowej samorządu lokalnego w Mołdawii świadczy również fakt, że zaledwie 17\% gmin jest w stanie zapewnić sobie funkcjonowanie bez wsparcia finansowego władz centralnych (Ionescu, Drezgie, Rusu, 2015, s. 11).

Istotnym problemem mołdawskiego samorządu lokalnego jest brak decentralizacji finansowej. Mimo ustawowej samodzielności jednostek administracyjno-terytorialnych, codzienną praktyką jest ingerencja władz centralnych w działalność gmin i rejonów, co częściowo związane jest $\mathrm{z}$ faktem, że władze centralne w istocie finansują funkcjonowanie większości z nich. W Mołdawii obowiązuje pośrednia dystrybucja środków wyrównujących poziom dochodów między gminami, w której pomiędzy rządem a gminami pośredniczy administracja rejonów. Wysokość otrzymywanych środków w znacznym stopniu zależy od charakteru nieformalnych relacji pomiędzy władzami gminy a władzami rejonu. O doniosłym znaczeniu tego aspektu świadczy fakt, iż do 80\% wpływów budżetowych gmin pochodzi z budżetu centralnego (Munteanu, Chiriac, Berbeca, Vremis, Znaceni, 2017, s. 17). Choć kilkukrotnie nowelizowana ustawa z dn. 16.10.2003 r. o finansach $i$ własności jednostek administracyjno-terytorialnych wprowadza obecnie bardziej transparentne procedury podziału środków, wskazuje się - m.in. w stanowisku Banku Światowego - że nie przynosi ona wymiernych efektów, zwłaszcza dla najmniejszych gmin (Moldova Public Expenditure Review, 2013). Za podział środków pomiędzy gminami odpowiedzialne są władze rejonów. Proces ten odbywa się przede wszystkim nie według określonej formuły, lecz w toku negocjacji pomiędzy władzami gminy i rejonu. W wyniku tego wysokość środków, którymi dysponują gminy może istotnie się różnić.

Pewną zmianą w realizacji zadań publicznych przez jednostki samorządu terytorialnego było wprowadzenie od 2014 roku budżetów zadaniowych. Są to jednak - wobec skali problemów związanych z niedofinansowaniem samorządów - niewielkie postępy na drodze reform.

Problemy we wdrażaniu polityki regionalnej. Ze względu na istotne dysproporcje w rozwoju społeczno-ekonomicznym kraju, polityka regionalna Mołdawii ma charakter dystrybucyjno-wyrównawczy. Głównym zadaniem jest zatem optymalizacja warunków funkcjonowania poszczególnych jednostek administracyjno-terytorialnych, uwzględniając konieczność wsparcia obszarów najmniej rozwiniętych. Współpraca po- 
między władzami centralnymi a jednostkami samorządu terytorialnymi rodzi jednak okresowe konflikty. W latach 2012-2014 rząd podjął działania na rzecz wypracowania modelu konsolidacji gmin i rejonów celem zwiększenia ich efektywności. Propozycje spotkały się ze sprzeciwem Kongresu Władz Lokalnych Mołdawii, które oponowały odgórnym propozycjom, ale również broniąc korzystnego dla nich status quo.

Duże znaczenie w określeniu mechanizmu współpracy władz centralnych $\mathrm{z}$ jednostkami samorządu terytorialnego posiada przyjęta 28.12.2006 r. ustawa o rozwoju regionalnym (Lege $\mathrm{nr} 438-\mathrm{XVI}$ ). Wprowadziła ona podział państwa na 6 regionów: Północ, Centrum, Południe, Kiszyniów, Gagauzję i Naddniestrze. 11.07.2012 r. została przyjęta w drodze ustawy Narodowa Strategia Rozwoju „Mołdawia 2020” (Lege nr 166), która wprowadziła rady rozwoju regionalnego z udziałem rozmaitych interesariuszy, w tym przedstawicieli samorządu lokalnego. Strategia zakłada redukcję dysproporcji w rozwoju społeczno-gospodarczym pomiędzy jednostkami samorządu terytorialnego i całymi regionami, kohezję oraz narzędzia dobrego zarządzania (good governance). Poprawę efektywności lokalnych administracji publicznych przewiduje również rządowy program Zrównoważone Cele Rozwojowe do roku 2030 oparty na Programie Narodów Zjednoczonych ds. Rozwoju (Toolkit for the Nationalization). Choć realizacja zadań postępuje powoli, władze Mołdawii deklarują kontynuację wysiłków. Świadczyć o tym może opublikowana w 2016 roku „Mapa drogowa decentralizacji” (Final Monitoring Report).

\section{Zakończenie}

Ogółem wskazać należy, że współczesny model samorządu lokalnego w Mołdawii, po krótkim okresie reform zmierzających ku decentralizacji, wciąż jest scentralizowany i bliski rozwiązaniom przejętym z czasów radzieckich. Brak politycznej woli elit państwowych oraz lokalnych działaczy (bardziej urzędników niż samorządowców) sprawia, że samorząd lokalny pozostaje jednym z zaniedbanych pól europeizacji mołdawskiego systemu politycznego. Głównym problemem pozostaje nadmierne rozdrobnienie jednostek administracyjno-terytorialnych, faktyczna kontrola i ograniczenie samorządności gmin przez rejony oraz finansowe uzależnienie gmin od transferów z budżetu centralnego. Odrębną kwestią, aczkolwiek nie mniej ważną i niemożliwą do zadekretowania, jest niska 
świadomość społeczna znaczenia idei samorządności oraz specyficzna, postradziecka kultura polityczna. Rekapitulując, nawet drobne kroki ku wzmocnieniu samorządu lokalnego i decentralizacji Mołdawii należy oceniać za właściwe, zaś na ich znaczące efekty będzie trzeba czekać długo.

\section{Bibliografia}

Czachor R. (2015), Postradzieckie rezimy polityczne w perspektywie neopatrymonialnej. Wstęp do badań, Wrocław.

Final Monitoring Report, Moldova: Local Public Finance Reform, https://www. zmos.sk/download_file_f.php?id=759006, 17.09.2018.

Ionescu A., Drezgie S., Rusu I. (2015), Report on the Territorial-Administrative Structure Options for the Republic of Moldova, http://www.md.undp.org/ content/moldova/en/home/library/inclusive_growth/report-on-the-territorialadministrative-structure-options-for-t.html, 1.09.2018.

Konstytucja Mołdawii (2014), wstęp i thumaczenie B. Zdaniuk, Wyd. Sejmowe, Warszawa.

Kosienkowski M. (2007), Geneza, status i funkcjonowanie Terytorium Autonomicznego Gagauzja, „Stosunki Międzynarodowe”, nr 3-4 (t. 36).

Lege nr 123-XV, Monitorul oficial al Republicii Moldova, 2003, nr 49.

Lege nr 166, Monitorul oficial al Republicii Moldova, 2012, nr 245-247.

Lege nr 173-XVI, Monitorul oficial al Republicii Moldova, 2005, nr 101-103.

Lege nr 186-XIV, Monitorul oficial al Republicii Moldova, 1999, nr 14-15.

Lege nr 191-XIV, Monitorul oficial al Republicii Moldova, 1998, nr 116.

Lege nr 306-XIII, Monitorul oficial al Republicii Moldova, 1995, nr 3-4.

Lege nr 344-XIII, Monitorul oficial al Republicii Moldova, 1995, nr 3-4.

Lege nr 397-XV, Monitorul oficial al Republicii Moldova, 2003, nr 248-253.

Lege nr 431-XIII, Monitorul oficial al Republicii Moldova, 1995, nr 31-32.

Lege nr 435-XVI, Monitorul oficial al Republicii Moldova, 2007, nr 29.

Lege nr 436-XVI, Monitorul oficial al Republicii Moldova, 2007, nr 32-35.

Lege nr 438-XVI, Monitorul oficial al Republicii Moldova, 2007, nr 21-24.

Lege nr 764-XV, Monitorul oficial al Republicii Moldova, 2002, nr 16.

Lege nr 768-XIV, Monitorul oficial al Republicii Moldova, 2000, nr 34.

Lege nr 1381-XIII, Monitorul oficial al Republicii Moldova, 1997, nr 81.

Moldova Public Expenditure Review. Capital Expenditures: Making Public Investment Work for Competitiveness and Inclusive Growth in Moldova, http:// documents.worldbank.org/curated/en/853711468054245749/pdf/763100 ESW0Mold0h0PUBLIC00Box379856B.pdf, 17.09.2018 r. 
Munteanu I., Chiriac L., Berbeca V., Vremis M., Znaceni A. (2017), State of Local Democracy in Moldova, Stockholm-Chisinau.

Regulamentul Găgăuziei - Gagauz Yeri, Uchwała nr 28-XXX/1 z dn. 5.06.1998 r., http://www.e-democracy.md/files/elections/gagauzia2006/regulations-gagauzia-ro.pdf, 17.09.2018.

Toolkit for the Nationalization of sustainable Development Goals, https://cancelaria. gov.md/sites/default/files/document/attachments/toolkit_onu_en_0.pdf, 17.09.2018 r.

Макухин А. (2017), Реформа административно-территориального деления и местного самоуправления в Республике Молдова: между институциональной теорией и политической практикой, „Eastern Review”, t. 6.

\title{
The structure of local government in the Republic of Moldova. Evolution and present state
}

\begin{abstract}
Summary
Moldova is an Eastern European country which is undertaking efforts to democratize and Europeanize its political and legal systems, but is doing so in a chaotic and inconsistent manner, which reflects the current political situation. One of the fields of political tensions is local government. The aims of the following paper are twofold: firstly, to describe the consecutive stages of the development of local government in Moldova; and, secondly, to describe the current model of Moldovan local government and its main problems.
\end{abstract}

Key words: local government, democratization, decentralization of power, Moldova 